\title{
Yerli ve Yabancı Ürünlerin Satın Alma Niyetinde Ekonomik Milliyetçiliğin ve Küresel Bilinçliliğin Etkisi
}

\author{
Nil Esra Dal ${ }^{1}$ \\ Illknur Korkmaz ${ }^{2}$
}

\begin{abstract}
Yerli ve Yabancı Ürünlerin Satın Alma Niyetinde Ekonomik Milliyetçiliğin ve Küresel Bilinçliliğin Etkisi
\end{abstract}

Öz

Kültürel çeşitlilik ve coğrafi sınırlamalara rağmen ülkeler, teknoloji, medya, çok uluslu evlilikler ve göç ile birlikte birbirine bağlı hale gelebilmektedir. Küreselleşme ülkeleri birbirine bağımlı hale getirse de, ilk önce ülke çıkarını önemseyen ekonomik milliyetçilik bu bağımlılığı yavaşlatan bir etken olabilecektir. Ancak, kendini dünya toplumunun üyesi olarak gören ve tüm insanlara karşı sorumluluk duygusu hisseden küresel bilinçlilik ise küreselleşmeden beslenebilecektir. Uluslararası pazarda tüketicilerin satın alma niyetlerinde ekonomik milliyetçiliğin ve küresel bilinçliliğin etkisinin araştırılması bu açıdan önemlidir. Bu çalışmada; ekonomik milliyetçiliğin ve küresel bilinçliliğin yerli ve yabancı ürünlerin satın alma niyetindeki etkisi araştırılmıştır. İstanbul'da yaşayan tüketicilere çevrimiçi anket ve kolayda örnekleme yöntemi ile ulaşılmıştır. Araştırma sonucunda; yerli ürünlerin satın alma niyetinde ekonomik milliyetçiliğin pozitif, küresel bilinçliliğin ise negatif etkisi olduğu tespit edilmiştir.

Anahtar Kelimeler: Ekonomik Milliyetçilik, Küresel Bilinçlilik, Satın Alma Niyeti, Yerli Ürün, Yabancı Ürün.
The Effect of Economic Nationalism and GlobalMindedness on The Purchase Intention of Domestic and Foreign Products

\section{Abstract}

Despite cultural diversity and geographical limitations, countries can become interconnected with technology, media, multinational marriages and migration. Although globalization makes countries dependent on each other, economic nationalism which firstly cares about the country's interest, may be a factor that slows down this dependence. However, global-mindedness, which sees itself as a member of the world community and feels a sense of responsibility towards all people, can be feed from globalization. In this respect, it is important to investigate the impact of economic nationalism and global-mindedness on the purchase intentions of consumers in the international market. In this study; the effect of economic nationalism and global-mindedness on the purchase intention of domestic and foreign products was investigated. Consumers living in Istanbul were reached with online survey and easy sampling method. As a result of the research; it is determined that economic nationalism has a positive, global-mindedness has a negative effect on purchase intention of domestic products.

Keywords: Economic Nationalism, Global-Mindedness, Purchase Intention, Domestic Product, Foreign Product.

\section{Giriş}

Temelinde ihtiyacın giderilmesi yatan tüketim, faydanın elde edilmesine dair bir amacı barındırmaktadır. İhtiyaç odaklı tüketim ile birlikte, kimi zaman ürün ya da hizmetin satın alımında fonksiyonellikten ziyade önemsenen başka unsurlar da etkili olabilmektedir. Ürün ya da hizmete faydanın yanı sıra kutsal, sosyal, hazcı, kültürel anlamlar, milli duygu ve değerler yüklenebilmektedir (İslamoğlu ve Altunışık, 2017: 66). Bu sebeple, tüketicilerin satın alma niyetlerinde ve satın alma davranışlarında ürünün temel işlevlerinin yanında, toplumun milli değerleri ile uyumlu ve milli faydayı sunan unsurlar da önemli olabilmektedir. Ancak, kimi zaman tüketicilerin satın alırken önemsediği faydalar, küresel etkinlikten oluşabilmektedir. Bu nokta-

\footnotetext{
${ }^{1}$ Dr. Öğr. Üyesi, Burdur Mehmet Akif Ersoy Üniversitesi, Bucak İşletme Fakültesi, İşletme Bölümü. Yazar ORCID bilgisi: nilesradal@mehmetakif.edu.tr, Yazar ORCID bilgisi: http://orcid.org/0000-0002-3089-8873

${ }^{2}$ Arş. Gör., Burdur Mehmet Akif Ersoy Üniversitesi, Zeliha Tolunay Uygulamalı Teknoloji ve İşletmecilik Yüksekokulu, Gümrük İşletme Bölümü, ikorkmaz@mehmetakif.edu.tr, Yazar ORCID bilgisi: http://orcid.org/0000-0002-9099-9633
} 
da, satın alma niyetlerinde tüketicilerin etkilendikleri unsurların neler olacağının bilinmesi pazarlama stratejileri için önem teşkil edecektir.

Küreselleşme, ülkeleri sadece ekonomik ve iletişim yönünden fiziki sınırlamalara rağmen bir araya getirebilmesinin yanında, sunduğu teknoloji ve medya olanakları ile birlikte küresel tüketici kültürünün de oluşmasına ortam hazırlamıştır. Tüketiciler, sadece yerli ürünlerden değil yabancı ürünlerden de faydalanabilme, ihtiyaç ve isteklerini karşılayan ürünleri menşei ülke fark etmeksizin değerlendirebilme olanağına sahip olmuştur. Küreselleşme, yarattığı küresel tüketici kültürü ile birlikte kendini dünya toplumunun bir üyesi olarak gören ve insanIığa karşı sorumluluk hisseden küresel bilinçli bireylerin (Hett, 1993) satın alma davranışına da etki edebilmiştir. Bu açıdan, milli çıkarı, ulusal gücü önemseyen ve "ilk önce biz" anlayışını güden ekonomik milliyetçilik (Baughn ve Yaprak, 1996) ile küresel bilinçliliğin tüketicilerin satın alma niyetlerindeki rolünün incelenmesi literatür için önem arz edecektir.

Araştırmanın amacı; tüketicilerin yerli ve yabancı ürünlere yönelik satın alma niyetlerinde ekonomik milliyetçilik ve küresel bilinçlilik düzeylerinin etkisini incelemektir. Bu amaç doğrultusunda, kolayda örnekleme metodu ile çevrimiçi anket uygulanarak 505 katılımcıya ulaşılmıştır. Araştırmada nicel bir yöntem benimsenmiş olup, verilerin analizinde frekans, normallik testi, geçerlilik ve güvenilirlik analizleri, regresyon analizi yapılmıştır. Araştırmada, yerli ürün satın alma niyetinde ekonomik milliyetçiliğin pozitif ve küresel bilinçliliğin ise negatif etkisi olacağı öngörüsünü destekler sonuca ulaşılmıştır.

\section{Kavramsal Çerçeve}

\subsection{Ekonomik Milliyetçilik}

Milliyetçilik olgusunun kavramsallaştırılması ve ölçülmesi ile ilgili çabalar 2. Dünya Savaşı sonrasında ortaya çıkmıştır. Kavramın ortaya çıkış sürecinin 2. Dünya Savaşı sonrasına denk gelmesinin sebebi; milliyetçiliğin bir savaş nedeni olarak görülmüş olmasıdır (Baughn ve Yaprak, 1996: 764). Ekonomik milliyetçilik kavramının ortaya çıkışının ise Leo Pasvolsky adlı yazarın 1928 yılında yayınladığı kitabında ele alması ile denk geldiği öngörülmektedir. 19. yüzyılda, ekonomik milliyetçilik serbest ticaretin karşısında duran korumacılık olarak ifade edilmiştir (Yiğenoğlu, 2016: 20).

Küreselleşmeyi yavaşlatan bir unsur olarak görülen ekonomik milliyetçilik, kavramsal olarak çeşitli yorumlara açık ve tanımlanması tartışmalı bir olgudur. Bu doğrultuda Burnell (1986), ekonomik milliyetçilik kavramının yeteri kadar incelenmediğini ifade ederek literatürde konu ile ilgili açığa ve kavramın netlik kazanmadığına değinmiştir (Akhter, 2007: 3). Ekonomik milliyetçilik özünde; ulusal kimlik ve milliyetçilikten beslenmektedir. Beslendiği ulusal kimliğin toplum ve kurumlar tarafından algılanması ise; içinde bulunan duruma, mekâna ve zamana göre değişerek şekil almakta ve böylece ekonomik milliyetçilik temelli politikalar tek tip olmaktan çıkmaktadır. Bu açıdan, ekonomik milliyetçilik ile ilgili tanımlamaların kolay ve tartışmasız bir şekilde kabul görmeyeceği ifade edilebilmektedir (Erkişi, 2017: 835). Bununla birlikte ekonomik milliyetçilik kavramı, birbirlerinden bağımsız olmayan ancak kavram bakımından farklı bakış açılarını ifade eden etnosentrizm, tüketici etnosentrizmi, vatanseverlik ve milliyetçilik gibi terimlerle karıştırılmaktadır. Bu durum da literatürde epistemolojik ve ontolojik sorunları beraberinde getirmektedir (Akhter, 2007: 3). Milliyetçilik ile vatanseverliği ayıran temel nokta; bireyin diğer ülkelere karşı beslediği olumsuz duygudur. Bu sebeple milliyetçilik; bireyin kendi ülkesinin ulusal egemenliğini önemseyen, ülkesiyle övünen ve bununla birlikte diğer ülkelere olumsuz duygular besleyerek ülkesi için fedakarlık yapan, ülkesini diğer ülkelere naza- 
ran üstün gören ve ülkesine yüksek sadakat duygusunu yaşayan hem siyasi bir ideoloji hem sosyolojik hem de ekonomik bir olgudur (Druckman, 1994: 44-48; Rawwas, 1996: 21; Akhter, 2007: 7; Balabanis vd., 2011: 160). Vatanseverlik ise; milliyetçiliğe göre daha ılımlı ve bireyin kendi ülkesi için diğer ülkelere karşı olumsuz duygular hissetmeden fedakarlıkta ve bağlılıkta bulunma halidir (Akhter, 2007: 7; Balabanis vd., 2011: 162). Sumner (1906) etnosentrizmi; bireyin bulunduğu ya da kendini ait hissettiği grubu her şey için merkez olarak benimsemesi, grubunun düşüncelerini ve davranışlarını referans alarak diğer grupları kendi grubuna göre ölçeklendirmesi ve derecelendirmesi durumu olarak tanımlamıştır. Dolayısıyla, bireyler ait olduğu grubun özelliklerini, değerlerini ve kültürünü üstün görmekte ve bu bakış açısıyla diğer grupları değerlendirmektedir (Sharma vd., 1995: 27). Bu sebeple, ekonomik milliyetçilik; bireylerin ithal ürünlere karşı önyargıda bulunması ve yerli ürünleri tercih etmesi iken, tüketici etnosentrizmi; ithal ürünlere karşı kültürel önyargı olarak ifade edilmektedir (Sharma vd., 1995: 26-27). Özellikle gelişmekte olan ülkelerde, milliyetçilik, vatanseverlik, etnosentrizm ve ekonomik milliyetçilik güçlü olabilmektedir. Bu açıdan, uluslararası faaliyet göstermek isteyen işletmelerin; hedeflenen dış pazarın sosyal davranışlarını, bu pazarın güçlü görülen ülkelerine duyulan bağııı̆̆ın şekillerini pazarlama açısından dikkate almaları ve değerlendirmeleri önem arz etmektedir (Altintaş ve Tokol, 2007: 321).

Ekonomik milliyetçiliğin temelinde ulusal gücü elde etmek ve bunu artırarak sürdürmek amacı yatmaktadır. Bu durum da ulusun birliğini ve gücünü zayıflatan politikaların uygulanmasını engelleyecektir (Nakano, 2004: 222). Tüketiciler yabancı ürünleri boykot ederek ve bu ürünleri satın almayı terk ederek, yabancı firmalarla iş anlaşmalarına yanaşmayarak ekonomik milliyetçilik göstermektedir (Akhter, 2007: 4). Devletler ise yerli üretimi ve işletmeleri yabancı işletmelerle olan rekabetinde korumaya yönelik ithalat vergileri, tarifeleri ve ticari engelleri uygulayarak ekonomik milliyetçilik yönelimli bir tavır sergilemektedir (Lee vd., 2014: 1134). Ekonomik milliyetçilik, ülkenin kalkınmasında itici bir güç olarak görünmekte ve yerli üretime yönelik yatırımı tercih etme ve teşvik etme eğilimini doğurmaktadır (Johnson, 1965: 169-173). Aynı zamanda ekonomik milliyetçilik, ülke vatandaşının gelirini ve refahını artıracak iş sunmayı amaç edinmektedir (Breton, 1964: 382). Dolayısıyla bir ülkenin ekonomik milliyetçilik seviyesi iç pazarının ve halkının ekonomik çıkarına göre değişim göstermektedir (Lan ve Li, 2014: 4). Yabancı bir yatırım yerli üretime ve ekonomiye yönelik bir tehdit rolüne sahip olduğunda ekonomik milliyetçilik korunma işlevini meydana getirecektir (Zhang ve He, 2014: 225). Girvan ise, ekonomik milliyetçiliğin emperyalizm ile mücadele etmede halkı teşvik eden bir araç olduğunu belirtmiştir (Girvan, 1975: 151). Bu açıdan ekonomik milliyetçilik, yabancı ürünlere yönelik ayrımda bulunma, yabancı iş̧̧ilerin ülkeye göç etmesine engel olma, diğer ülkelere ulusal şirketlerin yatırım yapmalarına karşı direnmeyi ve temelde ilk önce biz, kendi işletmelerimiz, kendi işçilerimiz, kendiişlerimiz ve kendi ürünlerimiz anlayışını barındıran bir olgudur (Baughn ve Yaprak, 1996: 765-772).

\subsection{Küresel Bilinçlilik}

Küreselleşme, fiziki ülke sınırlarına rağmen dünyada tüm farklı kültür ve coğrafyadaki insanları birleştiren ve gittikçe birbirine bağımlı hale getiren bir güçtür (Smith vd., 2010: 60). Dolayısıyla küreselleşme, ülke sınırlarının ekonomik, seyahat, iletişim gibi birçok alanda keskinliğini azaltmakla birlikte, çok uluslu şirketlerin olumlu bir imaja sahip olmasına yol açmasını ve uluslararası pazarda güç kazanmalarını sağlamıştır (Arı ve Madran, 2011: 16).

Farklı kültür ve coğrafyaya sahip olmasına rağmen ülkeler dünya ile kolay bir şekilde bağlantılı hale gelebilmektedir (Smith vd., 2010: 60). Bu bağlantı sadece mal ve hizmetlerin eko- 
nomik anlamda akışını değil kültürel anlamda da bir anlam ve bakış açısının akışını sağlamaktadır. Bu durum da yerel kültürlerin birbirine bağımlı hale gelmesiyle dünya kültürünü oluşturmuştur (Hannerz, 1990: 486). Göçün artması, farklı kültürlerin etkileşimi ile çok uluslu evliliklerin çoğalması, ülkeler arası mesafelerin teknolojinin ilerleyişi ile önemsiz hale gelmesi sonucu dünya sürekli bir dönüşüm içinde bulunmaktadır. Dolayısıyla, insanlar arasında dünya paylaşımının, ortak refahın, başka uluslara karşı empatinin artması, dünya dostluğunun benimsenmesi ve dünyaya yönelik kaygılar ile Sampson ve Smith (1957)'in de belirttiği gibi "dünya bilinçlilik" kavramı ortaya çıkmıştır (Rawwas, 1996: 20-21). Dünya bilinçlilik kavramını, sosyal bilimler alanı açısından çalışmalarında ilk ele alan Sampson ve Smith (1957) olmuştur (Nijssen ve Douglas, 2008: 88). Ancak, literatürde kozmopolitlik, kültürel açıklık ve dünya bilinçlilik ya da küresel bilinçlilik aynı anlamda ve birbirinin yerine geçecek şekilde kullanılmaktadır. Bu durumda kavram kargaşalığına yol açarak kavramın netlik kazanmasını tartışmalı hale getirebilmektedir. Kozmopolitlik ya da kozmopolitizm; diğer ülkelerle ve kültürlerle ilişki kurma, ülkeler arası seyahat etme isteği, daha fazla kültürle tanışma ve deneyimler yaşama isteği, tekdüzeliğin dışında çeşitliliğin ve karşıtlığın arayışı (Hannerz, 1990: 486-487) olan kültürel bir yönelimdir (Thompson ve Tambyah, 1999: 214). Kozmopolitizm, bireyin diğer kültürleri önyargı olmadan ve tamamen kabul etme durumudur (Nijssen ve Douglas, 2008: 86). Kültürel açıklık ise; bireylerin başka ülkelerle etkileşim kurma (Shankarmahesh, 2006: 149), başka kültürlere, farklı etnik kökene sahip insanlara, farklı kültürlerin değerlerine ve eserlerine olan açıklık durumu ve bu farklılığı deneyimleme özelliğidir (Sharma vd., 1995: 28). Her ne kadar kozmopolitlik ya da kozmopolitizm ve kültürel açıklık kendi içinde aynı anlamları yansıtsa da dünya bilinçlilik ya da küresel bilinçlilik farklı bir kavramı ve anlayışı ifade etmektedir (Shankarmahesh, 2006: 149). Dünya bilinçlilik kavramı Sampson ve Smith (1957) tarafından ortaya atılırken, küresel bilinçlilik kavramı ise Hett (1993) tarafından literatüre kazandırımıştır. Sampson ve Smith (1957) açısından dünya bilinçlilik; bir bireyin insanlığın sorunları ile ilgili dünya görüşünü ifade etmektedir. Dolayısıyla, bireyin diğer kültürlerle iletişimde ve etkileşimde bulunmadan da dünya bilinçli bir yönelime sahip olması mümkün olabilmektedir. Ancak, kozmopolitlik ve kültürel açıklık; bireyin diğer kültürlerle iletişimini ve etkileşimini gerektirmesi yönünden dünya bilinçlilik veya küresel bilinçlilik ile ayrılmaktadır (Shankarmahesh, 2006: 149). Sampson ve Smith (1957), dünya bilinçli olan bir kişinin; uluslararası düzeyde sorumluluk almayı istediğini, insancıl tutum ve davranışlarda bulunduğunu, insan ve hayvan haklarını önemsediğini, yoksulluk, ekolojik kaygı gibi unsurlara ilgi gösterdiğini belirtmiştir (Nijssen ve Douglas, 2008: 87). Hett, Sampson ve Smith (1957)'in geliştirdiği dünya bilinçlilik ölçeğinin; küresel bilinçliliğinin bazı yönlerini anlamada ve açıklamada temel işleve sahip olduğunu, oluşturulduğu zamanın ve dönemin koşullarının endişeleri ve değerleri ile kısıtlı kaldığı, ölçeğin maddelerinin bir dünya devleti ya da uluslararası düzeyde görev alan güvenlik teşkilatı ile ilgili olduğunu belirtmiştir. Bu sebeple Hett, etnik değere verdiği önemin ve bu yönde geliştirilen küresel bilinçlilik kavramının 1950'li yıllardan daha farklılık gösterdiğini ifade etmiştir. Dolayısıyla Hett, dünya bilinçliliği revize etmek yerine küresel koşullara ve anlayışına uygun küresel bilinçlilik kavramını ortaya atmıştır. Hett küresel bilinçliliğ̈i; bir bireyin dünya toplumuna kendini bağlı gördüğü ve dünya toplumunun üyelerine karşı sorumluluk hissi duyduğu bir dünya görüşü olarak tanımlamıştır. Küresel bilinçli bireyler, bu anlayışı tutumlarında, değerlerinde ve davranışlarında görünür kılmaktadır. Böylece, küresel bilinçli bireyler dünyayı daha yaşanılır kılma ve koşulları iyileştirme amacı güden topluluklara gönüllü katılmakta veya parasal destekte bulunmakta, çevresel konularda ve sorunlarda aktif olarak çalışmaktadır. Ayrıca küresel bilinçli bireyler, diğer ülkeler ve kültürleri hakkında, siyasi durumlar ve dünya toplumunu ya da 
bir ülkeyi etkileyen güncel olaylarda bilgi almakta ve tutumlarını dile getirmektedir (Hett, 1993).

\subsection{Satın Alma Niyeti}

Niyet; davranışı oluşturmada etkisi olan motive edici bir unsur olmakla birlikte, bireyin bir davranışı gerçekleştirmeye ne derece istekli olduğunun da simgesidir (Ajzen, 1991: 181). Satın alma niyeti ise, tüketicilerin satın alma karar süreçlerinde kritik bir işleve sahip olan ve maruz kaldığı uyarıcılara verdiği cevaplardan biridir (Arslan, 2003: 99). Bu doğrultuda satın alma niyeti, tüketicinin ihtiyaç duyduğu ve bu ihtiyacını fark ettiği andan itibaren ürün ya da hizmeti satın alma yönünde tercihte bulunmasıdır. Tüketicinin ihtiyaç duyduğu ürün ya da hizmetlere yönelik tutum ve algıları da satın alma niyetini oluşturmaktadır (Mutlu vd., 2011: 53).

Ürünün üretildiği ülke ve imajı tüketicilerin satın alma niyetlerini (Vida ve Reardon, 2008: 35) ve ürün değerlendirmelerini etkileyebilmektedir (Bilkey ve Nes, 1982: 90). Milliyetçilik ve küresel bilinçlilik satın alma kararlarında kuzey ve güney kutbu gibi iki ayrı uç noktada ve zıt yönde değildir (Rawwas, 1996: 22). Küresel pazar ortamında ülkeler ekonomik olarak gün geçtikçe birbirine daha bağımlı hale gelmektedir. Bu esnada, tüketicilerin yabancı ürünleri satın alma niyetleri ve buna yönelik tutumları önem kazanmaktadır. Aynı zamanda küresel bilinçli tüketicilerin de yerli ve yabancı ürünlere yönelik satın alma niyetleri ve tutumlarının anlaşılması gerekmektedir (Jourdan, 2001: 336). Dolayısıyla, tüketicilerin yerli ve yabancı ürünleri tercih etmesinde etkili olan unsurların araştırılması tüketicilerin iç pazarda gösterdikleri davranışlarının ve niyetlerinin anlaşılmasında önemli olacaktır (Sharma vd., 1995: 26).

\section{Literatür İncelemesi}

Pazarlama literatüründe ekonomik milliyetçilik ve küresel bilinçlilik konuları henüz yeteri kadar çalışıımış değildir. Tüketiciler satın alma niyetlerinde ürünün kalitesi, fonksiyonelliğinin yanında ürünün yerli ya da yabancı ürün olup olmadığını önemseyebilmekte ve bu doğrultuda satın alma kararı verebilmektedir. Bu açıdan, literatürde yazarlar ekonomik milliyetçilik ve küresel bilinçlilik konularına ilgi göstermiştir.

\subsection{Ekonomik Milliyetçilik İle ilgili Ölçümler}

Rawwas, milliyetçi tüketicilerin yabancı ürünleri satın almasının vatansever bir davranış olmadığını, bu davranışın da hem iç pazara zarar verdiğini hem de işsizliğe yol açtığını ifade etmiştir (Rawwas, 1996: 20). Akhter, Japonya örnekleminde ekonomik milliyetçiliğin hükümet, yerli şirketler ve halk tarafından algılanışına göre üç faktörlü bir ölçek geliştirmiştir. Akhter çalışmanın sonucunda; küreselleşmenin ekonomik milliyetçiliği tetikleyici ve güçlendirici bir unsur olduğunu, bu sebeple uluslararası işletmelerin yabancı ülke pazarına girdiğinde elde etmeyi istediği faydadan ziyade, ülkenin ekonomisine kazandıracağı faydayı önemsemesi gerektiğini belirtmiştir (Akhter, 2007).

Baughn ve Yaprak (1996); korumacılık, yabancı yatırım, ABD'deki yabancı işletmeler, ABD işletmelerine destek, fikri mülkiyet, ABD'li işletmelerin yerli üretim için ihtiyaçları, Amerikan ürünü satın alma duygusu ile göçmenler konusundaki tüketicilerin tutumlarını ölçen 36 maddelik bir ölçek geliştirerek uygulamıştır. Ölçek oluşturulurken ilgili maddeler; Shimp ve Sharma (1987), Yavas, Yaprak ve Riecken (1980) ve Sampson ve Smith'in (1957) çalışmalarından alınmıştır. Analizler sonucunda 16 maddenin ekonomik milliyetçiliği daha iyi yansıttığı tespit edilmiştir. Bu 16 madde; yabancı işletmelere ve yabancı yatırımlara yapılan kısıtlamalar, yabancı ürünlere getirilen engeller, yerli ürün satın alma isteği, işçi göçüne uygulanan sınırlamalar, yerli üretim, fikri mülkiyet ve rekabet ile ilgili temalardan oluşmaktadır. Çalışmanın sonucunda 
Baughn ve Yaprak; ekonomik milliyetçiliğin yabancı rakiplerin yansıttığı ekonomik tehdit algısı ile tahmin edildiğini; dolayısıyla algılanan ekonomik tehdidin ekonomik milliyetçiliğin önemli ve güçlü bir işareti olduğunu tespit etmişlerdir. Ayrıca yazarlar; ekonomik milliyetçiliğin uluslararasıcılık, açıklık ve kozmopolitlik ile olumsuz yönde ilişki gösterdiğini de ortaya çıkarmışlardır (Baughn ve Yaprak, 1996). Zhang ve He, Çin örnekleminde ekonomik milliyetçiliğin sınır ötesi kazanımların ulusal güvenlik, büyüme stratejisi ve dış ilişkilerden etkilendiğini bulgulamıştır (Zhang ve He, 2014: 223). Lee vd., Baughn ve Yaprak (1996)'ın ekonomik milliyetçilik ölçeğini kullanarak; Güney Kore ve Tayvan örnekleminde ekonomik milliyetçiliğin ve kozmopolitizmin tüketici davranışlarındaki etkisini ölçen bir çalışma yapmışlardır. Çalışmanın sonucunda yazarlar; ekonomik milliyetçilik ve kozmopolitizm arasında ilişki görülmediğini ve ekonomik milliyetçiliğin yerli ürünlere karşı daha güçlü seyrettiğini, kozmopolitizmin ise daha önyargılı ilişki gösterdiğini tespit etmiştir (Lee vd., 2014: 1133). Literatürdeki incelemeler doğrultusunda H1 hipotezi şu şekilde kurulmuştur:

H1: Ekonomik milliyetçiliğin yerli ve yabancı ürünlerin satın alma niyeti üzerinde istatistiki olarak anlamlı ve pozitif bir etkisi vardır.

\subsection{Küresel Bilinçlilik İle İlgili Ölçümler}

Literatürde bazı çalışmalarda dünya bilinçlilik olarak ele alınsa da, Hett (1993) ile birlikte kavram küresel bilinçlilik olarak da ölçülmüştür. Volgy ve Quistgaard, dünya düzeni amacıyla Birleşmiş Milletler'de ulusal rol alma türünün ve dünya bilinçliliğin arasında da bir ilişkinin tespit edildiğini ortaya çıkarmışlardır (Volgy ve Quistgaard, 1975: 368). Hett çalışmasında; sorumluluk, kültürel çoğulculuk, etkinlik, küresel merkezcilik ve karşılıklı bağlılık olan 5 faktörlü ve 30 maddeden oluşan bir küresel bilinçlilik ölçeği geliştirmiştir. Sorumluluk boyutunun; tüm insanlar için koşulları iyileştirmeye yönelik duyulan ahlaki sorumluluk ve kaygıdır. Kültürel çoğulculuk; kültür çeşitliliğini ve bu çeşitliliğin değerlerine önem vermedir. Etkinlik; uluslararası düzeyde fayda yaratabilmektir. Küresel merkezcilik; sadece kendi ülkesi için değil dünya için neyin iyi olduğunu düşünmek ve önemsemektir. Karşlıklı bağlılık ise; küresel topluma ait hissetmek, küresel aile olmaya ve tüm insanların akraba olduğuna inanmaktır (Hett, 1993).

Rawwas, Hett (1993) tarafından geliştirilen küresel bilinçlilik ölçeğini kullandığı çalışmada; milliyetçilik düzeyi yüksek olan tüketicilerin dünya bilinçliliği yüksek olan tüketicilere göre diğer ülkelerde üretilen yabancı ürünler konusunda farklılık göstererek ürünün menşei ülkesini daha çok önemsediklerini tespit etmiştir. Aynı zamanda Rawwas, milliyetçilik düzeyi yüksek olan tüketicilerin yerli ürünleri, dünya bilinçliliği yüksek olan tüketicilerin ise yabancı ürünleri daha kaliteli olarak algıladıkları sonucuna da ulaşmıştır (Rawwas, 1996: 33). Jourdan çalışmasında; Fransız ve Amerikan öğrencilerin dünya bilinçlilik, kozmopolitlik ve etnosentrizm eğilimlerini ölçerek, öğrencilerin dünya bilinçlilik düzeyinde farklılık olduğunu tespit etmiştir. Ayrıca çalışmada, bir kültüre maruz kalma durumu arttıkça dünya bilinçlilik düzeyinin de arttığı ortaya çıkmıştır (Jourdan, 2001: 336-337). Nijssen ve Douglas ise, Hollanda'da dünya bilinçlilik, sosyal bilinçlilik, diğer kültürlere maruz kalma ve mağaza imajı arasındaki ilişkiyi inceleyen bir çalışma yapmışlardır. Çalışmanın sonucunda yazarlar; tüketicilerin yabancı bir kültüre maruz kalma durumunun dünya bilinçlilik ve sosyal bilinçlilik düzeyini arttırdığına ve bu durumun da yabancı ülkelerin geleneksel ürünlerini satan mağazaların imajlarını olumlu yönde etkilediğine ulaşmışlardır (Nijssen ve Douglas, 2008). Literatür incelemesi doğrultusunda H2 hipotezi şu şekilde oluşturulmuştur:

H2: Küresel bilinçliliğin yerli ve yabancı ürünlerin satın alma niyeti üzerinde istatistiki olarak anlamlı ve negatif bir etkisi vardır. 


\section{Metodoloji}

\subsection{Amaç ve Önem}

Araştırmanın amacı; tüketicilerin yerli ve yabancı ürünlere yönelik satın alma niyetlerinde ekonomik milliyetçilik ve küresel bilinçlilik düzeylerinin etkisini incelemektir. Mevcut ekonomik süreç içerisinde tüketicilerin yerli ve yabancı ürünlere yönelik tutumlarının ve satın alma niyetlerinin belirlenmesi; iç pazarda gerçekleşen ekonomik durumu kişilerin ekonomik milliyetçilik ve küresel bilinçlilik ekseninde gösterebilmesi açısından hem literatür hem de pazarlama uygulayıcıları ve sektör için bu çalışma önem arz etmektedir.

\subsection{Kapsam ve Yöntem}

Araştırma evreni; İstanbul'da yaşayan tüketicilerdir. Araştırmanın örneklem yöntemi olarak; ihtiyaç duyulan örneklem sayısına ulaşmada en kolay veri elde edilmesine imkan veren kolayda örneklem yöntemi uygulanmıştır. Evren 10.000 .000 ve üzerinde bir büyüklüğe sahipse örneklemin \%95 güven aralığında 384 olması makul kabul edilebilmektedir (Gürbüz ve Şahin, 2016: 132-134). TÜiK (2017) yıllara göre il nüfus verileri incelendiğinde; İstanbul'un 2017 nüfusu 15.029.231'dir. İstanbul'da yaşayan 505 katılımcıya nicel bir yöntem benimsenerek çevrimiçi anket metodu ile ulaşılmıştır. Çalışmanın anketi katılımcıların İstanbul'da yaşayıp yaşamadıkları sorusu ile başlanmıştır. İstanbul dışında yaşayan katılımcılar çalışmaya dahil edilmemiştir. Ancak, yapılan analizler sonucunda uç değerler tespit edilerek silinmiş ve 491 anket formu geriye kalmıştır.

Çevrimiçi anket formunda; araştırmanın amacını ölçmesi planlanan ölçekler ile demografik sorular yer almaktadır. Araştırmada kullanılan ölçekler; Baughn ve Yaprak (1996)'ın çalışmasında yer alan 16 maddelik ekonomik milliyetçilik ölçeği, Hett (1993)'in doktora tezinde oluşturduğu 5 faktörlü ve 30 maddelik küresel bilinçlilik ölçeği ve Klein vd. (1998)'nin geliştirdiği 6 maddelik satın alma niyeti ölçeği Türkçe'ye uyarlanarak ve bağlama uygunluğu test edilerek kullanılmıştır.

\subsection{Model ve Hipotezler}

Araştırmanın modelinde yer alan bağımsız değişkenler; ekonomik milliyetçilik ve küresel bilinçliliktir. Bağımlı değişken ise; yerli ve yabancı ürünlerin satın alma niyetidir. Araştırma modeli Şekil 1'de gösterilmiştir.

Şekil 1: Araştırma Modeli

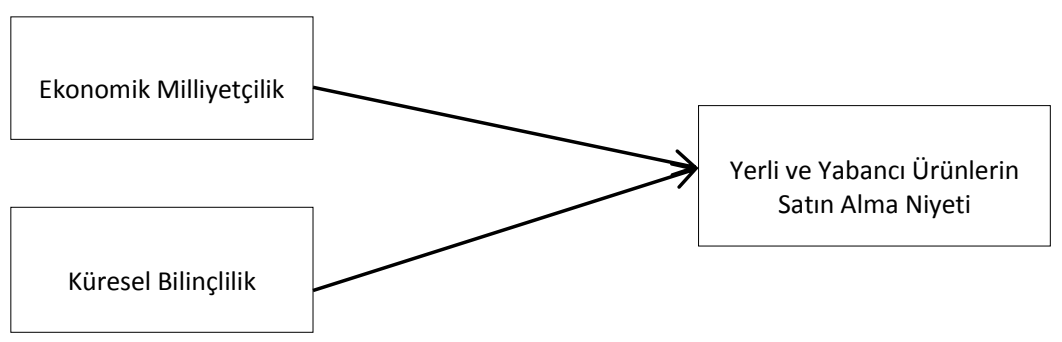

Araştırmanın ana hipotezleri ise şu şekilde oluşturulmuştur:

H1: Ekonomik milliyetçiliğin yerli ve yabancı ürünlerin satın alma niyeti üzerinde istatistiki olarak anlamlı ve pozitif bir etkisi vardır. 
Eskişehir Osmangazi Üniversitesi ïBF Dergisi

H2: Küresel bilinçliliğin yerli ve yabancı ürünlerin satın alma niyeti üzerinde istatistiki olarak anlamlı ve negatif bir etkisi vardır.

\section{Bulgular}

\subsection{Frekans Analizi}

491 katılımcının demografik bilgilerini veren frekans analizi bulguları Tablo 1'de gösterilmiştir.

Tablo 1: Demografik Bulgular

\begin{tabular}{|c|c|c|}
\hline Demografik Bilgiler & Frekans (f) & $\begin{array}{c}\text { Yüzde } \\
\text { (\%) }\end{array}$ \\
\hline \multicolumn{3}{|l|}{ Cinsiyet } \\
\hline Kadın & 394 & 80,2 \\
\hline Erkek & 97 & 19,8 \\
\hline Toplam & 491 & 100 \\
\hline \multicolumn{3}{|l|}{ Yaş } \\
\hline 18 yaş altı & 13 & 2,6 \\
\hline $18-24$ yaş & 202 & 41,1 \\
\hline $25-34$ yaş & 175 & 35,6 \\
\hline $35-44$ yaş & 64 & 13,0 \\
\hline $45-54$ yaş & 24 & 4,9 \\
\hline 55 yaş ve üstü & 13 & 2,6 \\
\hline Toplam & 491 & 100 \\
\hline \multicolumn{3}{|l|}{ Meslek } \\
\hline Öğrenci & 72 & 14,7 \\
\hline Nitelikli Uzman Meslekler (Akademisyen, Doktor, Öğretmen, Avukat vb.) & 30 & 6,1 \\
\hline Özel Sektör Çalışanı (İş̧̧i, Meslek Elemanı vb.) & 120 & 24,4 \\
\hline Kamu Çalışanı (Uzman, Memur, Polis vb.) & 7 & 1,4 \\
\hline Serbest Meslek & 24 & 4,9 \\
\hline İşsiz & 44 & 9,0 \\
\hline Ev Hanımı & 151 & 30,8 \\
\hline Emekli & 12 & 2,4 \\
\hline Diğer & 31 & 6,3 \\
\hline Toplam & 491 & 100 \\
\hline \multicolumn{3}{|l|}{ Eğitim Durumu } \\
\hline İlköğretim & 42 & 8,6 \\
\hline Ortaöğretim & 83 & 16,9 \\
\hline Lise & 188 & 38,3 \\
\hline
\end{tabular}




\begin{tabular}{lcc}
\hline Üniversite & 172 & 35,0 \\
Lisansüstü & 6 & 1,2 \\
Toplam & 491 & 100 \\
Aylık Gelir & & \\
1000 TL'den az & 197 & 40,1 \\
$1000-3000$ TL & 246 & 50,1 \\
$3001-5000$ TL & 39 & 7,9 \\
5001 TL ve üstü & 9 & 1,8 \\
Toplam & 491 & 100 \\
\hline
\end{tabular}

Tablo 1'deki demografik bulgular incelendiğinde; kadın katılımcıların oranının $(\% 80,2)$ erkek katılımcılardan $(\% 19,8)$ yüksek olduğu görülmektedir. Yaş aralığının yoğun olarak 18-24 yaş $(\% 41,1)$ ve $25-34$ yaş $(\% 35,6)$ aralığında toplanması katılımcıların çoğunlukla genç kişilerden oluştuğu söylenebilir. Meslek olarak en fazla ev hanımı $(\% 30,8)$ ve özel sektör çalışanı (işçi, meslek elemanı vb.) $(\% 24,4)$ gruplarında yoğunluk görüldüğü gözlenmiştir. Katılımcıların eğitim durumları çoğunlukla lise $(\% 38,3)$ ve üniversite $(\% 35)$ seviyesindedir. Aylık gelirleri genel olarak 1000-3000 TL $(\% 50,1)$ ve 1000 TL'den az $(\% 40,1)$ olduğu tespit edilmiştir.

\subsection{Geçerlilik ve Güvenilirlik Analizleri}

Ölçeklerin mevcut örneklemde geçerliliğini sınamak için amacına uygun istatistik programlarında açımlayıcı ve doğrulayıcı faktör analizi yapıımış ve güvenilirliği de Cronbach Alpha değeri ile ölçülmüştür.

Açımlayıcı faktör analizi, ölçeklere madde ekleme-çıkarma işlemi yapılıyor, gözlenen değişkenlerin hangi faktörler altında toplandığı, değişkenlerin faktör yük katsayıları, faktörlerin açıkladıkları varyans oranın yorumlanması gibi nedenlerden ötürü yapısal ve faktöriyel geçerlilik çalışmalarına açımlayıcı faktör analizi ile başlanmasının daha uygun olacağı kabul edilmektedir. Doğrulayıcı faktör analizinde ise, test edilen modelin mevcut örneklemde doğrulanmasına dair birtakım uyum iyiliği katsayıları ile daha belirgin bir şekilde ortaya konulması mümkündür. (Gürbüz ve Şahin, 2016: 310). Dolayısıyla çalışmada kullanılan ölçeklerin, hangi faktörlere ayrıldığını ve faktörlerin literatüre uygun ne şekilde adlandırılacağını, ölçeklerden hangi maddelerin çıkarılacağını tespit etmek amacıyla ilk önce açımlayıcı faktör analizi yapılmıştır. Daha sonra, açımlayıcı faktör analizi sonucunda oluşan ölçeklerin mevcut örneklemde doğrulanması için ise doğrulayıcı faktör analizi yapılmıştır.

\subsubsection{Açımlayıcı Faktör Analizi ve Güvenilirlik Analizi}

Açımlayıcı faktör analizinde yer alan KMO değerinin >80 çıkması ölçeğin açımlayıcı faktör analizine çok iyi olduğunu göstermektedir (Kalaycl, 2010: 322). Özdeğer >1 değerler faktör sayısını belirlemektedir (İslamoğlu, 2003: 191). Toplam açıklanan varyans yüzdesinin; tek boyutlu bir ölçek ise minimum \%30, birden fazla faktörlü ölçek ise minimum \%50 olması makuldür (Gürbüz ve Şahin, 2016: 312). Cronbach alpha değeri ölçeğin güvenilirlik derecesini gösterir ve bu değerin minimum 0,70 olması istenilmektedir (Gürbüz ve Şahin, 2016: 309-325).

16 maddeli ve tek boyutlu olan ekonomik milliyetçilik, 5 faktörlü ve 30 maddeli küresel bilinçlilik, 6 maddeli ve tek boyutlu satın alma niyeti ölçeklerinin açımlayıcı faktör analizi ve güvenilirlik analizi sonuçları Tablo 2, 3 ve 4'te yer almaktadır. 
Eskişehir Osmangazi Üniversitesi iißBF Dergisi

Tablo 2: Ekonomik Milliyetçilik Ölçeği Açımlayıcı Faktör Analizi ve Güvenilirlik Analizi

\begin{tabular}{lccccc}
\hline Faktörler ve Maddeler & Oçılanan & Cronbach & Özdeğer & $\begin{array}{c}\text { Faktör } \\
\text { Varyans }\end{array}$ & Alpha
\end{tabular}

\section{Faktör: Ticari Korumacılık}

Türk şirketlerinin yabancı şirketlerle olan rekabetinde kazanması önemlidir.

Türk teknolojisinin yabancı şirketlere devri daha sıkı bir şekilde kontrol edilmelidir.

Uluslararası patent ve telif hakkı yasaları Türkiye'nin çıkarlarını vurgulamalıdır.

Türkiye'deki yabancı şirketlerin faaliyetleri hükümet tarafından sıkı bir şekilde denetlenmelidir.

Diğer ülkelerle olan ticari ilişkilerimizde, Türkiye'nin zirvede olması önemlidir.

Türk işçilerini daha fazla istihdam etmek için, göçü sınırlandırmak ile ilgili daha çok şey yapmalıyız.

Sadece kendi ülkemizden elde edemeyeceğimiz ürünleri yabancı ülkelerden satın almalıyız.

Eğer bizim işçilerimiz için dezavantaj oluşturacaksa, göçmenlerin Türkiye'ye gelmesine izin verilmemelidir.

\section{Faktör: Ekonomik Yaptırım}

Yurtdışında iş yapan Türk şirketleri ülkesini yüz üstü bırakmaktadır.

Türk şirketleri, üretimlerini diğer ülkelere taşırlarsa cezalandırılmalıdır.

Diğer ülkelerde üretilen ürünleri satın alan Türk tüketiciler, Türklerin işsiz kalmasından sorumludur.

\section{Faktör: Yabancı Yatırım Kısıtlaması}

Türkiye'deki yabancı yatırımlar kısıtlanmalıdır.

Türkiye'ye yapılan yabancı yatırım, Türkiye'nin ekonomik güvenliğine yönelik bir tehdittir. 
Toplam Açılanan Varyans Yüzdesi

Ölçek Güvenilirliği

Ölçek Ortalaması

KMO: 0,90

Bartlett's Küresellik Testi Ki-Kare: 2858,431

Serbestlik Derecesi (df): 120

p (Sig.): 0,000

1-Kesinlikle Katılmıyorum, 2-Katılmıyorum, 3-Ne Katılıyorum, Ne Katılmıyorum, 4-Katılıyorum, 5-Kesinlikle Katılıyorum

16 maddeli ve tek boyutlu ekonomik milliyetçilik ölçeği; açımlayıcı faktör analizi sonucunda öz değeri 1'de büyük olan 3 faktör vardır. Ölçeğin toplam açıklanan varyans yüzdesi 55,67'dir. Ölçeğin KMO değeri ise; 0,90 olup açımlayıcı faktör analizi için ölçeğin çok iyi olduğunu göstermektedir. Cronbach alpha değeri; 0,86 olup ölçeğin güvenilir olduğu bulgulanmıştır. Ölçek maddelerinin ortalaması "Ithalat tamamen engellenmelidir" ile "Türk şirketleri, üretimlerini diğer ülkelere taşırlarsa cezalandırılmalıdır" maddeleri hariç 4'e yakın ve $\geq 4$ olduğundan katılımcıların ekonomik milliyetçilik düzeylerinin yüksek olduğu söylenebilmektedir. Katılımcıların her ne kadar ekonomik milliyetçilik düzeyleri yüksek olsa da ithalata tamamen karşı durmadığı söylenebilir. Ölçeğin genel ortalaması ise 3,73'tür. Ölçekte en yüksek ortalama ise "Türk şirketlerinin yabancı şirketlerle olan rekabetinde kazanması önemlidir" $(4,31)$ maddesine aittir. Bu da; uluslararası pazarda Türk şirketlerinin önde olmasının arzulandığını göstermektedir.

Tablo 3: Küresel Bilinçlilik Ölçeği Açımlayıcı Faktör Analizi ve Güvenilirlik Analizi
Ort.

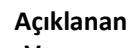

Açılklanan
Varyans

Cronbach

Alpha
Özdeğer Faktör

\section{Faktör: Sorumluluk Odaklı Küresel Merkezcilik}

Gelecek nesiller üzerinde olumlu bir etkisi olacak kariyer isterim.

Dünyada binlerce insanın aç kaldığını duyduğumda, kendimi hayal kırıklığına uğramış hissederim.

İnsanların gelecek nesiller ile ilgili mevcut politikaları anlamaları için eğitilmesi önemlidir.

Bazen aç olan bir insanın nasıl hissettiğini hayal etmeye çalışıyorum.

Türk değerleri en iyisidir.*

Dünya çapındaki insan kaynaklı afetler oldukça moral bozucudur.

Gelecek nesiller için yarattığımız dünya hakkında sürekli düşünürüm.

Türkiye, diğer ülkelerle olan müzakerelerde menfaatlerimizi ön planda tutmalıdır.* 
Türk eğitim sistemi farklı etnik ve kültürel geçmişe

sahip insanları teşvik etmelidir.

Ulusal politikalar hakkındaki düşüncelerim, bu politikaların sadece Türkiye'yi değil dünyanın geri kalanını da nasıl etkilediğine dayanmaktadır.

Türkiye muhtemelen dünya ülkelerinin birbirleri ile daha bağlantılı hale gelmesinden yarar sağlayacaktır.

Dünyanın herhangi bir yerinde insanların yaşam standartlarını gördüğümde, bunun hakkında yapmam gereken bir şey olduğunu düşünürüm.

Baskıcı rejimlerde yaşayan insanlar için çok endişeliyim.

Dünyanın zenginliklerinin ve kaynaklarının mevcut dağılımı korunmalıdır. Çünkü bu en güçlü olanın yaşamını sürdürmesi ve zayıfların yok olması ilkesini teşvik eder.*

İnsanların davranışlarını kültürleri bağlamında anlamaya çalışmaktan zevk alırım.

Türkler çevreye olumsuz etkisini görmezden gelseler bile güçlerinin yettiği yaşam standardını yakalamaya çalışmalıdır.*

Devletimizin yanlış olduğunu düşündüğüm bir şey yaptığını gördüğümde kendimi konuşmaya mecbur hissederim.

\section{Faktör: Kültürel Çoğulculuk}

Türkiye, farklı ülkeler ve kültürlerdeki insanlarla zenginleştirilmelidir.

Türkler dünyadaki farklı kültürlerden değerli şeyler öğrenebilir.

Başka kültürlerden insanlarla akşam sohbet etmeyi severim.

Kendimi sadece bir Türk değil, bir dünya vatandaşı olarak da görürüm.

\section{Faktör: Küresel Bağlılık}

Kendimi küresel toplumun bir üyesi olarak görmem.*

Diğer ülkelerdeki insanlarla çok az ortak noktam var.*

Dünya ve dünyanın sorunları hakkında gerçekten yapabileceğim hiçbir şey yoktur.*

Bazen diğer ülkelerdeki insanlardan rahatsızlık duyuyorum. Çünkü Türkiye'deki işlerin nasıl yürüdüğünü 


\section{Faktör: Küresel Etkinlik}

Dünya çapında insanlarla güçlü bir akrabalık hissederim.

Yapacağım şeyin diğer ülkelerdeki insanları etkileyeceğini düşünürüm.

$$
0,62
$$

Kendi toplumumda yaptığım bir şeyle küresel düzeyde bir etki yaratabilirim.

Türklerin dünyada daha az imkâna sahip insanlarla varlıklarını paylaşmaları ahlaki bir zorunluluktur.

\section{KMO: 0,94}

\section{Bartlett's Küresellik Testi Ki-Kare: 6196,263}

Serbestlik Derecesi (df): 435

p (Sig.): 0,000

1-Kesinlikle Katılmıyorum, 2-Katılmıyorum, 3-Ne Katılıyorum, Ne Katılmıyorum, 4-Katılıyorum, 5-Kesinlikle Katılıyorum

*Ters kodlanmıştır.

5 faktörlü olan küresel bilinçlilik ölçeği açımlayıcı faktör analizi sonucunda 4 faktöre ayrılmıştır. Toplam açıklanan varyans yüzdesi; 51,20 ve KMO değeri; 0,94 olduğu için ölçeğin açımlayıcı faktör analizi için çok iyi düzeyde olduğu anlaşılmaktadır. Cronbach Alpha değerinin 0,73 olması ölçeğin güvenilir olduğunu göstermektedir. Ölçeğin madde ortalamaları genel olarak 4' e yakın ve 4 olduğundan, katılımcıların küresel bilinçlilik düzeylerinin yüksek olduğu anlaşımaktadır. Ölçek ortalaması 3,42 olup ekonomik milliyetçilik ölçeğinin ortalamasından daha düşüktür. Bu durum da katılımcıların ekonomik milliyetçilik düzeylerinin küresel bilinçlilik düzeyine göre daha yüksek olduğunu göstermektedir. En yüksek ortalamaya sahip "Sorumluluk Odaklı Küresel Merkezcilik" faktörü olup en yüksek ortalamaya sahip madde ise "Gelecek nesiller üzerinde olumlu bir etkisi olacak kariyer isterim" $(4,32)$ dir.

Tablo 4: Yerli ve Yabancı Ürünlerin Satın Alma Niyeti Ölçeği Açımlayıcı Faktör Analizi ve Güvenilirlik Analizi

\begin{tabular}{|c|c|c|c|c|}
\hline Maddeler & Ort. & $\begin{array}{c}\text { Açıklanan } \\
\text { Varyans } \\
\text { Yüzdesi }\end{array}$ & $\begin{array}{c}\text { Cronbach } \\
\text { Alpha }\end{array}$ & Özdeğer \\
\hline $\begin{array}{l}\text { Mümkün olduğunca, yabancı ürünleri satın almaktan kaçını- } \\
\text { rım. }\end{array}$ & 3,63 & & & \\
\hline Yabancı ürünlere sahip olma fikrinden hoşlanmam. & 3,36 & 63,62 & 0,85 & 3,18 \\
\hline Yabancı bir ürünü satın alırsam, kendimi suçlu hissederim. & 3,23 & & & \\
\hline Asla yabancı bir ürünü satın almam. & 2,81 & & & \\
\hline
\end{tabular}


Eğer yabancı ve yerli ürün eşit kalitede olursa, yerli ürüne

\%10 daha fazla öderim.

Ölçek Ortalaması

KMO: 0,84

Bartlett's Küresellik Testi Ki-Kare: 1100,613

Serbestlik Derecesi (df): 10

p (Sig.): 0,000

1-Kesinlikle Katılmıyorum, 2-Katılmıyorum, 3-Ne Katılıyorum, Ne Katılmıyorum, 4-Katılıyorum, 5-Kesinlikle Katılıyorum

Yerli ve yabancı ürünlerin satın alma niyeti ölçeği açımlayıcı faktör analizi sonucunda 1 madde (mümkün olduğunca, yabancı ürünleri satın almayı tercih ederim) çıkartılarak ölçek 6 maddeden 5 maddeye inmiş ve tek boyut olarak sonuç vermiştir. Açıklanan varyans yüzdesi; 63,62 ve KMO değeri ise; 0,84 olup ölçeğin açımlayıcı faktör analizi için çok iyi olduğunu göstermektedir. Cronbach alpha değeri; 0,85 olup ölçeğin güvenilir olduğu tespit edilmiştir. Ölçeğin madde ortalamalarına bakıldığında; yerli ürün satın alma niyetlerinin yüksek olduğu ve katılımcıların mümkün olduğunca yabancı ürün kullanmaktan kaçındıkları görülmektedir. Ancak, katılımcılar yerli ürün satın almayı tercih etse de yabancı ürünü satın almayı tamamen reddetmemekte, bundan kendini suçlu hissetmemekte ve hoşnutsuz olmamaktadır. En yüksek ortalama ise "Eğer yabancı ve yerli ürün eşit kalitede olursa, yerli ürüne \%10 daha fazla öderim" $(3,80)$ olup katılımcıların yerli ürün satın alma niyetlerinin yüksek olduğu anlaşılmaktadır.

\subsubsection{Doğrulayıcı Faktör Analizi}

Ölçeklerin mevcut örneklemde doğruluğunu ve yapı geçerliliğini test etmek amacıyla doğrulayıc faktör analizi yapılmıştır. Doğrulayıcı faktör analizinin uyum indeksleri ile ilgili olması gereken kesme noktaları Tablo 5'te ve çalışmada kullanılan ölçeklerin doğrulayıcı faktör analizi sonuçları ise Tablo $6^{\prime}$ da gösterilmiştir.

\section{Tablo 5: DFA Uyum indeksleri Ile ilgili Kesme Noktaları}

\begin{tabular}{lll}
\hline Uyum Indeksleri & Kesme Noktaları & Kaynak \\
\hline CMIN/DF & $\leq 2,5=$ mükemmel uyum & (Kline, 2005) \\
& $\leq 5=$ orta düzeyde uyum & (Sümer, 2000) \\
& $\geq 0,85=$ kabul edilebilir uyum & (Steiger, 1990) \\
GFI & $\geq 0,90=$ iyi uyum & (Schumacker, Lomax, 1996). (Sümer, \\
& $\geq 0,95=$ mükemmel uyum & 2000) \\
& $\geq 0,80=$ kabul edilebilir uyum & (Steiger, 1990) \\
AGFI & $\geq 0,90=$ iyi uyum & (Schumacker, Lomax, 1996). (Sümer, \\
\end{tabular}




\begin{tabular}{|c|c|c|}
\hline & $\geq 0,90=$ iyi uyum & \\
\hline \multirow[t]{2}{*}{ CFI } & & \\
\hline & $\geq 0,95=$ mükemmel uyum & (Sümer, 2000) \\
\hline RMSEA & $\leq 0,08=$ iyi uyum & (Tabachnick, Fidell, 2001) \\
\hline
\end{tabular}

Tablo 6: Doğrulayıcı Faktör Analizi Sonucu Ölçeklerin Uyum Indeksleri Ile ilgili Kesme Noktaları

\begin{tabular}{|c|c|c|c|c|c|c|}
\hline Ölçekler & $\mathbf{p}$ & CMIN/DF & GFI & AGFI & CFI & RMSEA \\
\hline Ekonomik Milliyetçilik & ,000 & 3,036 & 919 & ,902 & 918 & ,064 \\
\hline Küresel Bilinçlilik & 000 & 2,428 & ,881 & ,859 & 905 & 054 \\
\hline $\begin{array}{l}\text { Yerli ve Yabancı Ürünlerin Satın } \\
\text { Alma Niyeti }\end{array}$ & ,003 & 4,023 & 987 & ,952 & 989 & 079 \\
\hline
\end{tabular}

Tablo 5'te belirtilen uyum indeksleri ile ilgili kesme noktaları ile Tablo 6'da gösterilen ölçeklerin kesme noktaları uyum göstermiş olup; ölçeklerin mevcut örneklemde doğrulandığı ispat edilmiştir.

\subsection{Normallik Testi}

Ölçeklerin normal dağııımı için basıklık ve çarpıklık değerine bakılmıştır. Tablo 7'de de gösterildiği üzere ölçeklerin çarpıklık ve basıklık değeri -2 ve +2 aralığında dağılmaktadır. Bu durum da ölçeklerin normal dağıldığını göstermektedir (George ve Mallery, 2003).

Tablo 7: Faktör Analizi Sonucu Ölçeklerin Normal Dağılımı

\begin{tabular}{lccc}
\hline Ölçekler & N & Çarpıklık & Basıklık \\
\hline Ekonomik Milliyetçilik & 491 &,- 787 & 1,008 \\
Küresel Bilinçlilik & 491 &,- 527 &, 522 \\
Yerli ve Yabancı Ürünlerin Satın Alma Niyeti & 491 &,- 288 &,- 668 \\
\hline
\end{tabular}

\subsection{Regresyon Analizi}

Ekonomik milliyetçilik ile küresel bilinçliliğin yerli ve yabancı ürünlerin satın alma niyeti üzerinde etkisini tespit etmek amacıyla çoklu regresyon analizi yapılmıştır. Regresyon analizi yapılmadan önce değişkenler arasında ilişkinin korelasyon analizi ile ortaya çıktığı tespit edilmiştir. Analiz sonuçları Tablo 8 ve Tablo 9'da gösterilmiştir. 
Eskişehir Osmangazi Üniversitesi ïBß Dergisi

Tablo 8: Değişkenler Arasındaki Korelasyon Analizi

\begin{tabular}{lccc}
\hline Değişkenler & $\mathbf{1}$ & $\mathbf{2}$ & $\mathbf{3}$ \\
\hline 1. Ekonomik Milliyetçilik & - & \\
2. Küresel Bilinçlilik &, $49^{* *}$ & - \\
3. Yerli ve Yabancı Ürünlerin Satın Alma Niyeti &, $59^{* *}$ &, $19^{* *}$ & - \\
\hline
\end{tabular}

Tablo 9: Regresyon Analizi Sonuçları

\begin{tabular}{|c|c|c|c|c|c|c|c|c|c|c|}
\hline $\begin{array}{c}\text { Bağımsız } \\
\text { Değişkenler }\end{array}$ & $\begin{array}{l}\text { Bağımlı } \\
\text { Değişken }\end{array}$ & $\mathbf{R}^{2}$ & Beta & $\mathbf{T}$ & $\begin{array}{l}t \text { sig. } \\
\text { (p) }\end{array}$ & D-W & Tolerans & VIF & $\begin{array}{l}\text { Artıkların } \\
\text { Çarpıklığı }\end{array}$ & $\begin{array}{c}\text { Artıkların } \\
\text { Basıklığı }\end{array}$ \\
\hline Ekonomik & & & & & & & ,752 & & & \\
\hline & $\begin{array}{l}\text { Yerli ve } \\
\text { Yabancı }\end{array}$ & & 96 & 15,78 & ,000 & & & 1,330 & & \\
\hline Küresel & $\begin{array}{l}\text { Ürünlerin } \\
\text { Satın Alma }\end{array}$ & ,36 & & & & 2,01 & & &,- 280 & 176 \\
\hline & Niyeti & &,- 34 & $-3,09$ & ,002 & & 752 & 1,330 & & \\
\hline
\end{tabular}

F değerinin anlamlılık düzeyi modelin anlamlı olduğunu ve $t$ değeri ise değişkenlerin tek başına anlamlılığını göstermektedir (Kalaycı, 2010: 268). F ve t değerinin anlamlı olduğu Tablo 9 'da belirtilmiştir $(p<0,05)$. Beta değerine bakıldığında; ekonomik milliyetçilik için pozitif, küresel bilinçlilik için ise negatif etki gösterdiği görülmüştür. Dolayısıyla ekonomik milliyetçiliğin yerli ve yabancı ürünlerin satın alma niyetinde pozitif, küresel bilinçliliğin ise negatif etkisi olduğu tespit edilmiştir. $\mathrm{H} 1$ ve $\mathrm{H} 2$ hipotezleri desteklenmiştir. $\mathrm{R}^{2}$ değeri; bağımlı değişken üzerindeki değişimin ne kadarının bağımsız değişkenler tarafından açıklandığını göstermektedir (Gürbüz ve Şahin, 2016: 272). $R^{2}$ değeri ,36 olup; yerli ve yabancı ürünlerin satın alma niyetinde gerçekleşen değişmenin \%36'lık kısmının ekonomik milliyetçilik ve küresel bilinçlilik düzeyi ile açıklandığını belirtmektedir. Tolerans değeri $<0,2$ ve VIF değeri $>10$ ise değişkenlerin arasında çoklu bağlantı sorunu vardır (Gürbüz ve Şahin, 2016: 273). D-W değerinin ise 1,5-2,5 aralığında olması otokorelasyon olmadığını göstermektedir (Kalaycı, 2010: 264). Analiz sonucunda; modelde çoklu bağlantı ve otokorelasyon olmadığı tespit edilmiştir. Artıkların çarpıklık ve basıklık değerleri -1 ve +1 arasında dağıldığından değişkenler normal dağılım göstermiştir (Tabachnick ve Fidell, 2013).

\section{Sonuç}

Çalışmanın demografik bulguları sonucunda; örneklemi oluşturan katılımcıların çoğunluğunun kadın ve gençlerden oluştuğu saptanmıştır. Katılımcıların meslek grupları incelendiğinde ise; ev hanımı ve özel sektör çalışanlarının ağırlıkta olduğu söylenebilir. Ayrıca katılımcıların eğitim seviyelerinin ise; lise ve üniversite düzeyinde olduğunu tespit edilmiştir. 
Araştırmada ekonomik milliyetçilik, küresel bilinçlilik ve yerli ve yabancı ürünlerin satın alma niyeti ölçekleri kullanılmıştır. Ekonomik milliyetçilik ölçeğinin maddelerinin ortalaması incelendiğinde; "Ithalat tamamen engellenmelidir" ile "Türk şirketleri, üretimlerini diğer ülkelere taşırlarsa cezalandırılmalıdır" maddeleri dışındaki ifadelere "katılıyorum" ve "kesinlikle katılıyorum" yanıtlarını verdikleri tespit edilmiştir. Dolayısıyla, katılımcıların ekonomik milliyetçilik düzeylerinin yüksek olduğu söylenebilir. Katılımcıların her ne kadar ekonomik milliyetçilik düzeyleri yüksek olsa da ithalata tamamen karşı durmadıkları da dikkat çekmektedir. Katılımcılar, ölçek ifadelerine genel olarak "katılıyorum" $(3,73)$ yanıtını vermiştir. Ölçekte katılımcıların en çok katıldıkları; "Türk şirketlerinin yabancı şirketlerle olan rekabetinde kazanması önemlidir" $(4,31)$ ifadesidir. Bu sonuç; katılımcıların uluslararası pazarda Türk şirketlerinin önde olmasını arzulandıklarını göstermektedir.

Araştırmanın bir diğer ölçeği olan küresel bilinçlilik ölçeğinin ifadelerine de katılımcılar genel olarak katıldıklarını vurgulamıştır. Buna göre; katılımcıların küresel bilinçlilik düzeylerinin yüksek olduğu anlaşılmaktadır. Katılımcıların küresel bilinçlilik ölçeğine katılım düzeylerinin ekonomik milliyetçilik ölçeğine göre daha düşük olduğu $(3,42)$ söylenebilir. Bir başka deyişle; katılımcıların ekonomik milliyetçilik düzeylerinin küresel bilinçlilik düzeyine göre daha yüksektir. Katılımcıların en çok katıldıkları ifade "Sorumluluk Odaklı Küresel Merkezcilik" faktörünün altında yer alan "Gelecek nesiller üzerinde olumlu bir etkisi olacak kariyer isterim" $(4,32)$ maddesidir. Küresel bilinçlilik ölçeği literatürde; sorumluluk, kültürel çoğulculuk, etkinlik, küresel merkezcilik ve karşılıklı bağlılık olarak boyutlandırılmıştır. Ancak, bu çalışmada ölçek faktörleri; sorumluluk odaklı küresel merkezcilik, kültürel çoğulculuk, küresel bağlılık ve kültürel etkinlik olarak isimlendirilmiştir.

Yerli ürün ve yabancı ürünlerin satın alma niyeti ölçeğine verilen yanıtlar incelendiğinde; yerli ürün satın alma niyetlerinin yüksek olduğu ve mümkün olduğunca yabancı ürün kullanmaktan kaçındıkları görülmektedir. Ancak, katılımcılar yerli ürün satın almayı tercih etse de yabancı ürünü satın almayı tamamen reddetmemekte, yabancı ürün satın almaktan kendini suçlu hissetmemekte ve hoşnutsuz olmamaktadır. Katılımcıların yerli ürün satın alma niyeti yüksek olmasına rağmen yabancı ürünleri satın alma niyetinden vazgeçmemeleri dikkat çekici bir durumdur. "Eğer yabancı ve yerli ürün eşit kalitede olursa, yerli ürüne \%10 daha fazla öderim" $(3,80)$ katılımcıların en çok katıldıkları ifade olduğu ortaya çıkmıştır.

Ekonomik milliyetçilik ve küresel bilinçlilik düzeyinin yerli ve yabancı ürünlerin satın alma niyetine etkisi regresyon analizi incelenmiştir. Regresyon analizi sonucunda; Beta değerinin ekonomik milliyetçilik için pozitif, küresel bilinçlilik için ise negatif etki gösterdiği görülmüştür. Dolayısıyla ekonomik milliyetçiliğin yerli ve yabancı ürünlerin satın alma niyetinde pozitif, küresel bilinçliliğin ise negatif etkisi olduğu tespit edilmiştir. Başka bir açıdan; ekonomik milliyetçilik düzeyi yükselmesinin tüketicilerin yerli ürün satın alma niyetini yükselttiği, küresel bilinçlilik düzeyinin yükselmesinin ise tüketicilerin yerli ürün satın alma niyetini azalttığı söylenebilir. Yerli ve yabancı ürünlerin satın alma niyetinde değişmenin \%36'lık kısmının ekonomik milliyetçilik ve küresel bilinçlilik düzeyi ile açıklandığını ortaya çıkmıştır.

Akhter (2007)'e göre küreselleşme ekonomik milliyetçiliği tetikleyici ve güçlendirici bir unsurdur. Uluslararası işletmeler, ekonomik milliyetçiliğin yüksek olduğu pazarlara girdiğinde, en çok yabancı ülkenin ekonomisine kazandıracağı faydayı önemsemesi gerekmektedir. Baughn ve Yaprak (1996) ise, algılanan ekonomik tehdidin ekonomik milliyetçiliğin önemli ve güçlü bir işareti olduğunu tespit etmişlerdir. Rawwas, milliyetçilik düzeyi yüksek olan tüketicilerin yerli 
ürünleri, dünya bilinçliliği yüksek olan tüketicilerin ise yabancı ürünleri daha kaliteli olarak algıladıkları sonucuna da ulaşmıştır (Rawwas, 1996: 33).

Literatürde ekonomik milliyetçiliğin uluslararasıcılık, açıklık ve kozmopolitlik ile ilişkisini araştıran çalışmalara rastlanmıştır. Baughn ve Yaprak (1996), ekonomik milliyetçiliğin uluslararasıcılık, açıklık ve kozmopolitlik ile olumsuz yönde ilişki gösterdiğini ortaya çıkarmışlardır (Baughn ve Yaprak, 1996). Lee vd. (2014), ekonomik milliyetçilik ve kozmopolitizm arasında ilişki görülmediğini tespit etmişlerdir. Bu çalışmada ise, ekonomik milliyetçilik ve küresel bilinçlilik arasında olumlu yönde ilişkinin olduğu ortaya çıkmıştır. Lee vd. (2014), ekonomik milliyetçiliğin yerli ürünlere karşı daha güçlü seyrettiği, kozmopolitizmin ise daha önyargılı ilişki gösterdiğini tespit etmiştir. Benzer şekilde bu çalışmada da, ekonomik milliyetçiliğin yerli ürünlere karşı daha güçlü seyrettiği tespit edilmiştir. Jourdan (2001)'ın Fransız ve Amerikan öğrencilerin dünya bilinçlilik, kozmopolitlik ve etnosentrizm eğilimlerini ölçtüğü çalışmasında, dünya bilinçlilik düzeyinin farklııı gösterdiği ortaya çıkmıştır. Yapılan çalışmanın sonucunda ise, küresel bilinçlilik yaş, eğitim ve mesleğe göre farklılık göstermiştir.

Pazarlamada makro çevresel faktörler, tüketicilerin satın alma davranışlarını etkilemektedir. Ancak, ürün ve hizmetlerin satın alınmasında esnasında durumsal faktörlerin de etkili olduğu bilinmektedir. Çalışmanın bu anlamda, makro çevresel ve durumsal faktörler de dikkate alındığında bir takım kısıtları mevcuttur. Dolayısıyla, çalışma sonuçları genellenebilir değildir. Çalışma sadece, yerli ve yabancı ürünlerin satın alma niyetinde ekonomik milliyetçilik ve küresel bilinçliliğin etkisini belirli bir örneklem çerçevesinde ele almıştır. İlerleyen çalışmalarda, belirli ürün kategorilerinde yerli ve yabancı ürün satın alma niyeti incelenebilir. Dışsal ve içsel faktörlerden etkilenen tüketici karar süreci karmaşık bir yapıya sahiptir. Dışsal ve içsel faktörlerin ayrıntılı bir şekilde ele alındığı çalışmalar yapılması mümkündür.

Tüketicilerin yerli ürün satın alma niyetlerin ve yabancı ürün satın almaya karşı tutumlarının ölçülmesi, pazarlama stratejilerinin geliştirilmesine katkı sağlayacaktır. Uluslararası pazarlarda, tüketicilerin ekonomik milliyetçilik ve küresel bilinçlilik eğilimlerinin araştırılması işletmelerin rekabet avantajı elde etmelerine yardımcı olacaktır. 


\section{Kaynaklar}

Ajzen, Icek (1991), "The Theory of Planned Behavior", Organizational Behaviior and Human Decision Processes, Vol.50, No.2: 179-211.

Akhter, Syed H. (2007), "Globalization, Expectations Model of Economic Nationalism, and Consumer Behavior", Journal of Consumer Marketing, Vol.24, No.3: 142-150.

Altintaş, Murat Hakan; Tokol, Tuncer (2007), “Cultural Openness and Consumer Ethnocentrism: An Empirical Analysis of Turkish Consumers", Marketing Intelligence \& Planning, Vol.25, No.4: 308-325.

Arı, Emin Sertaç; Madran, Canan (2011), "Satın Alma Kararlarında Tüketici Etnosentrizmi ve Menşe Ülke Etkisinin Rolü”, Öneri Dergisi, C.9, S.35: 15-33.

Arslan, Kahraman (2003), “Otomobil Alımında Tüketici Davranışlarını Etkileyen Faktörler”, İstanbul Ticaret Üniversitesi Fen Bilimleri Dergisi, C.2, S.3: 83-103.

Balabanis, George; Diamantopoulos, Adamantios; Mueller, Rene Dentiste; Melewar, T. C. (2011), "The Impact of Nationalism, Patriotism and Internationalism on Consumer Ethnocentric Tendencies", Journal of International Business Studies, Vol.32, No.1: 157-175.

Baughn, C. Christopher; Yaprak, Attila (1996), “Economic Nationalism: Conceptual and Empirical Development", Political Psychology, Vol.17, No.4: 759-778.

Bilkey, Warren J.; Nes, Erik (1982), "Country-of-Origin Effects on Product Evaluations", Journal of International Business Studies, Vol.13, No.1: 89-99.

Breton, Albert (1964), "The Economics of Nationalism”, Journal of Political Economy, Vol.72, No.4: 376-386.

Druckman, Daniel (1994), “Nationalism, Patriotism, and Group Loyalty: A Social Psychological Perspective”, Mershon International Studies Review, Vol.38, No.1: 43-68.

Erkişi, Kemal (2017), "Uluslararası Politik İktisat Perspektifinde İktisadi Milliyetçiliğin Kavramsal Analizi”, Uluslararası Sosyal Araştırmalar Dergisi, C.10, S.54: 827-837.

George, Darren; Mallery, Paul (2003), SPSS for Windows, Step by Step, A Simple Guide and Reference, Boston: Allyn and Bacon.

Girvan, Norman (1975), “Economic Nationalism”, Daedalus, Vol.104, No.4: 145-158.

Gürbüz, Sait; Şahin, Faruk (2016), Sosyal Bilimlerde Araştırma Yöntemleri Felsefe-Yöntem-Analiz, Ankara: Seçkin Kitabevi.

Hannerz, Ulf (1990), "Cosmopolitans and Locals in World Culture", Theory, Culture and Society, Vol.7, No.2-3: 486-491.

Hett, E. Jane (1993), "The Development of An Instrument to Measure Global-Mindedness", University Of San Diego Doctoral Thesis

İslamoğlu, Ahmet Hamdi (2003), Bilimsel Araştırma Yöntemleri, İstanbul: Beta Basım Yayım Dağıtım A.Ş.

İslamoğlu, Ahmet Hamdi; Altunışık, Remzi (2017), Tüketici Davranışları, İstanbul: Beta Basım Yayın Dağıtım A.Ş.

Johnson, Harry G. (1965), "A Theoretical Model of Economic Nationalism in New and Developing States", Political Science Quarterly, Vol.80, No.2: 169-185.

Jourdan Jr, Louis; Tillery, Kenneth; Deis, Michael (2001), “Worldmindedness, Cosmopolitanism, and Views of Purchasing Behavior in Two Cross-Cultural Student Groups", Business Journal for Entrepreneurs, Vol.3, No.4: 336-337.

Kalaycı, Şeref (2010), SPSS Uygulamalı Çok Değişkenli İstatistik Teknikleri, Ankara: Asil Yayın.

Kline, Rex B. (2005). Methodology in the social sciences. Principles and practice of structural equation modeling, 2 nd Ed., New York, NY, US: Guilford Press.

Lan, Xiaohuan; Li, Ben (2014), "The Economics of Nationalism", Boston College Working Papers in Economics 856, Boston College Department of $1-51$. https://www.bc.edu/content/dam/files/schools/cas_sites/economics/pdf/workingpapers/wp856.pdf, (Erişim: 08.11.2018).

Lee, Kyung Tae; Lee, You-II; Lee, Richard (2014), “Economic Nationalism and Cosmopolitanism: A Study of Interpersonal Antecedents and Differential Outcomes", European Journal of Marketing, Vol.48, No.5/6: 1133-1158.

Mutlu, H. Murat; Çeviker, Abdüllatif; Çirkin, Zeynep (2011), "Tüketici Etnosentrizmi ve Yabancı Ürün Satın Alma Niyeti: Türkiye ve Suriye Üzerine Karşılaştırmalı Analiz", Sosyoekonomi, C.14, S.44: 51-74. 


\section{Eskişehir Osmangazi Üniversitesi IïBF Dergisi}

Nakano, Takeshı (2004), "Theorising Economic Nationalism”, Nations and Nationalism, Vol.10, No.3: 211-229.

Nijssen, Edwin J.; Douglas, Susan P. (2008), "Consumer World-Mindedness, Social-Mindedness, and Store Image", Journal of International Marketing, Vol.16, No.3: 84-107.

Rawwas, Mohammed Y.A.; Rajendran, K.N.; Wuehrer, Gerhard A. (1996) “The Influence of Worldmindedness and Nationalism on Consumer Evaluation of Domestic and Foreign Products", International Marketing Review, Vol.13, No.2: 20-38.

Schumacker, Randall E.; Lomax, Richard G. (1996), A Beginner's Guide to Structural Equation Modeling, Hillsdale, NJ, US: Lawrence Erlbaum Associates, Inc.

Shankarmahesh, Mahesh N. (2006), "Consumer Ethnocentrism: An Integrative Review of Its Antecedents and Consequences", International Marketing Review, Vol.23, No.2: 146-172.

Sharma, Subhash; Shimp, Terence A.; Shin, Jeongshin (1995), “Consumer Ethnocentrism: A Test of Antecedents and Moderators", Journal of the Academy of Marketing Science, Vol.23, No.1: 26-37.

Smith, Daniel B.; Jayaratne, K. S. U.; Moore, Gary; Kistler, Mark J.; Smith, David (2010), "Factors Affecting the Global Mindedness of Extension Agents: Implications for Building Global Awareness of Extension Agents", Journal of International Agricultural and Extension Education, Vol.17, No.1: 59-67.

Steiger, James H. (1990), "Structural Model Evaluation and Modification: An Interval Estimation Approach", Multivariate Behavioral Research, Vol.25, No.2: 173-180.

Sümer, Nebi (2000), "Yapısal Eşitlik Modelleri: Temel Kavramlar ve Örnek Uygulamalar", Türk Psikoloji Yazıları, C.3, S.6: $49-74$.

Tabachnick, Barbara G.; Fidell, Linda S. (2001), Using Multivariate Statistics, 4th Ed., Boston: Allyn and Bacon.

Tabachnick, Barbara G.; Fidell, Linda S. (2013), Using Multivariate Statistics, 6th Ed., Boston: Pearson.

Thompson, Craig J.; Tambyah, Siok Kuan (1999), "Trying to Be Cosmopolitan", Journal of Consumer Research, Vol.26, No.3: 214-241.

Vida, Irena; Reardon, James (2008), “Domestic Consumption: Rational, Affective or Normative Choice?”, Journal of Consumer Marketing, Vol.25, No.1: 34-44.

Volgy, Thomas J.; Quistgaard, Jon E. (1975), “Learning About The Value of Global Cooperation: Role-Taking in The United Nations as A Predictor of World Mindedness", The Journal of Conflict Resolution, Vol.19, No.2: 349-376.

Yiğenoğlu, Kaan (2016), “iktisadi Milliyetçilik ve Artan Korumacılık Eğilimleri: ABD Otomotiv Sektöründe Korumacılığın Ekonomi Politiği", JOMELIPS, C.1, S.2: 17-37.

Zhang, Jianhong; He, Xinming (2014), "Economic Nationalism and Foreign Acquisition Completion: The Case of China", International Business Review, Vol.23, No.1: 212-227.

http://www.tuik.gov.tr/UstMenu.do?metod=temelist ${ }_{L}$ (Erişim: 28.11.2018). 